Yayın Geliş Tarihi: 25.01.2016

Yayına Kabul Tarihi: 18.03.2016

Online Yayın Tarihi: 02.06.2016

DOI: 10.18613/deudfd.51191

Derleme Makale-Review Article
Dokuz Eylül Üniversitesi

Denizcilik Fakültesi Dergisi

Cilt:8 Sayı:1 Yıl:2016 Sayfa:63-81

ISSN:1309-4246

E-ISSN: 2458-9942

\title{
INTEGRATION OF MARITIME TRANSPORTATION \\ TO SUPPLY CHAINS: A LITERATURE REVIEW AND SUGGESTIONS FOR FURTHER RESEARCH
}

\author{
Cansu YILDIRIM ${ }^{1}$ \\ D. Ali DEVEC $\dot{I}^{2}$
}

\begin{abstract}
The vivid increase in the world population pushes companies to attain for resources in a less expensive and rapid manner, which, in turn, increases the importance of maritime transportation, especially, for global resources' supply. Accordingly, the traditional role of ports in maritime transportation, creating a link between maritime and inland transport, has changed, and they have become networking sites where members of supply chains come together. This leads to a need for higher degree of coordination and cooperation, which indicates a requirement for integration to supply chains to meet the needs and demands of customers, and also to achieve higher levels of competitiveness. Although existing literature acknowledges this need, the number of studies is limited. This study, therefore, aims to specify and interpret the available literature about the integration of maritime transportation to supply chains with a focus on port integration, and accordingly suggest some further research ideas.
\end{abstract}

Keywords: Maritime transportation, supply chain, port integration, agency theory, resource-based view.

${ }^{1}$ Asst. Prof. Dr., Dokuz Eylül University, Maritime Faculty, İzmir, cansu.yildirim@deu.edu.tr

${ }^{2}$ Prof. Dr., Dokuz Eylül University, Maritime Faculty, İzmir, adeveci@deu.edu.tr 


\section{DENIZYOLU TAŞIMACILIĞININ TEDARIKK ZINCİRI ILE ENTEGRASYONU: KAYNAK TARAMASI VE GELECEK ARAŞTIRMALAR İÇİN ÖNERİLER}

\section{ÖZET}

Dünya nüfusunun hızlı artışı, şirketleri daha ucuz ve hızlı bir şekilde kaynaklara ulaşmaya zorlamıştır. Bu durum sonucunda ise denizyolu taşımacılı̆̆ının önemi, özellikle küresel tedarik bakımından, artmıştır. Geleneksel olarak denizyolu ve ülke içi arasında bağlantı oluşturan limanların rolü ise bu etkilerle değişmiş ve limanlar, tedarik zinciri üyelerinin bir araya geldiği ăglar haline gelmiştir. Bu durum daha yüksek koordinasyon ve işbirliği gerektirdiğinden, müşterilerin ihtiyaçlarını ve taleplerini karşılayabilmek adına deniz taşımacılı̆̆ının tedarik zincirlerine entegrasyonu ihtiyacını doğurmuştur. Önceki çalışmalar bu ihtiyacın varlı̆̆ını vurgulasa da, bu alandaki çalışmaların sayısı yeterli değildir. Bu çalışma deniz taşımacılı̆̆ının tedarik zincirlerine entegrasyonu hakkında, özellikle limanların entegrasyonu üzerinde yoğunlaşarak, var olan kaynaklarl incelemeyi ve buna bağll olarak gelecek araştırmalar için öneriler sunmayı hedeflemektedir.

Anahtar Kelimeler: Deniz taşımacıll̆̆ğ, limanların entegrasyonu, tedarik zinciri, vekâlet teorisi, kaynak temelli yaklaşım.

\section{INTRODUCTION}

In today's global world, for competing and surviving in severe market conditions and delivering goods and services effectively and efficiently, firms realize the importance of designing and coordinating their supply and distribution networks (Sengupta et al. 2006). Due to this need and several changes (i.e. changes in customer needs and in demand), the importance maritime transportation has enhanced. Accordingly, integration becomes a major concern for maritime transportation, especially for ports. Despite being acknowledged by previous literature, the number of empirical studies on this subject is limited. Thus, the aim of this research is to specify and interpret the available literature on integration of maritime transportation to supply chains, by focusing on port integration, and propose some further research ideas by utilizing interdisciplinary nature of maritime transportation.

In order to accomplish the coordination and design of supply and distribution networks, the concept of supply chain management (SCM) has coined, and described as: "the systematic, strategic coordination of the traditional business functions and the tactics across these business functions within a particular company and across businesses within the 
supply chain, for the purposes of improving the long-term performance of the individual companies and the supply chain as a whole" (Mentzer et al. 2001:18). With the management of supply chain, companies would gain competitive advantage through performance improvements in communication, and develop partnership and cooperation by achieving more efficient and effective flows of physical goods or services. Furthermore, such integration helps to achieve a desired level of customer service level by, for instance, fulfilling orders, or pre- and post-sales services (Stevens, 1989).

Nevertheless, since each partners' performance has an effect on the overall performance of the chain, these improvements could not be achieved at the expense of other partners in the supply chain (Croom et al. 2000). On the contrary; as mentioned above, the objective is to create an integrated chain for maximizing the performance of the entire chain since the whole is considered to be greater than the sum of its parts (Christopher, 2010). Therefore, SCM takes a systems approach in order to manage the whole supply chain as a single entity (Lummus et al. 2001) for satisfying market needs (Stevens, 1989).

For achieving supply chain integration, parties in the chain should cooperate with each other for reaching a mutually accepted outcome (Tongzon et al. 2009). This means there needs to be trust, coordination, and collaboration between the different partners in the supply chain (Burgess et al. 2006). Therefore, one of the enablers of supply chain integration is information sharing (Song and Panayides, 2008) which allows partners to share on time and open information for reducing problems of alignment (Croom et al. 2000). Besides, by information sharing, companies may benefit from cost reduction and performance improvement (Lee and Fernando, 2015) via avoiding duplication of documentation, improving dependability, reliability, and speed (Panayides and Song, 2009). Moreover, collaboration provides an opportunity to minimize the conflicts between partners in the chain, whereas coordination helps the whole chain to be more responsive to customer demands. These constructs highlight how the relationships between customers and suppliers have a key role in supply chain integration context (Song and Panayides, 2008). All of these aid the chain to achieve higher efficiency, lower costs, and higher quality (Xinyue and Yongli, 2008), thus become more competitive in the global market.

Above mentioned description and advantages demonstrates that the aim of SCM is the integration and coordination of all organizations and activities, which begins with sourcing of raw materials to deliver the 
products to final customer for gaining benefit from performance improvements of the whole channel not only one company in the chain (Alvarado and Kotzab, 2001). Thus, only with the development of an integrated supply chain would create competitive advantage for companies through helping them to react to the conditions of dynamic markets (Stevens, 1989).

Simultaneously, the dramatic increase in the world population forces companies to reach for resources in a less expensive and rapid manner, which, in turn, increases the importance of maritime transportation, especially, for the supply of global resources (Goss, 1982). Along with globalization, the characteristic of demand for maritime transportation and the nature of customer needs have also altered. Furthermore, the traditional role of ports within maritime transportation has changed, and they become networking sites, which gather members of the chain (Panayides, 2006; Yan and Qiang, 2008). Therefore, as the role of ports has changed (See Carbone and De Martino, 2003; Bichou and Gray, 2004; 2005; Notteboom and Rodrigue, 2005), a need occurs for higher degree of coordination and cooperation in order to be successful (Song and Panayides, 2008). Thus, supply chain integration/orientation of ports has become an interest in order to meet the needs and demands of customers, and to achieve port competitiveness (Tongzon et al. 2009).

These changes have enhanced the importance of maritime transportation and made it the dominant mode for international trade and also for supply chains (Mangan et al. 2008). Accordingly, integration, which may be physical (integration of modes of transport), economic/strategic (vertical integration, governance structure) or organizational (relational, people or process integration via organizations), emerges at the centre of maritime transportation, as well as ports (Panayides, 2006). Although current literature acknowledges the importance of integration to supply chains or supply chain orientation for ports, the number of empirical studies on these issues are limited (Song and Panayides, 2008; Tongzon et al. 2009; Panayides and Song, 2009). Therefore this study, by focusing on the port integration to supply chains, aims to specify and interpret the available literature about the concept, and accordingly suggest some further research ideas by utilizing the interdisciplinary nature of maritime transportation. 


\section{METHODOLOGY}

The aim of this research is to specify and interpret the available literature about integration of maritime transportation to supply chains with a focus on port integration, and provide some suggestions for future research. Articles investigating ports roles in supply chain, and port integration into supply chains are considered relevant for this research. For example, articles which have investigated the degree of seaport integrations into supply chains (i.e: Woo et al. 2013) are considered appropriate. For conducting this research, electronic databases, time frame and keywords were identified. Primarily, for including a different collection of publications (i.e: conference proceedings, books, thesis, journal articles), two databases were classified: Emerald and Science Direct. Additionally, a search of Internet (i.e: Google Scholar and Google) was carried out for finding the reports regarding the objective. Keywords for conducting the research were selected accordingly to the aim of the research (i.e: maritime transportation, maritime shipping, supply chain management, supply chain integration, port integration). Primarily, the research is focused on literature published between 2000 and 2016. Nevertheless, after finding relevant articles, their citations were cross-checked for not missing out any relevant publications (i.e: earlier publications).

The initial research from two databases provided 284 numbers of articles, conference proceedings, reports and books. Within these, there were publications from related fields such as logistics, but some of them are not directly related to this objective of the study (i.e: supplier evaluation, supply chain disruptions), so they were excluded. The total number of relevant documents was 24 , however, within these there were duplications. The end result of the initial research was 16 documents (See Table 1). The result of initial research in databases provided a broad diversity of sources such as International Journal of Logistics Management, Supply Chain Management: An International Journal, International Journal of Production Economics, and Journal of Transport Geography.

However, as it can be seen from the result, these databases exclude some key journals such as Maritime Policy and Management, and Maritime Economics \& Logistics therefore; a further research is conducted through Google Scholar (with same keywords) in order to avoid missing relevant information on the subject matter. This further research provided the documents presented in Table 2 . 
Table 1: Keyword Analysis

\begin{tabular}{|c|c|c|c|c|}
\hline Keyword & $\begin{array}{l}\text { Keyword } \\
\text { Extension }\end{array}$ & E-Database & $\begin{array}{c}\text { Total } \\
\text { Number } \\
\text { of } \\
\text { Articles }\end{array}$ & $\begin{array}{l}\text { Relevant } \\
\text { Number } \\
\text { of } \\
\text { Articles }\end{array}$ \\
\hline \multirow[t]{9}{*}{$\begin{array}{c}\text { Maritime } \\
\text { Transportation } \\
+ \text { Port } \\
\text { integration+ } \\
\text { Supply Chain } \\
\end{array}$} & $\begin{array}{l}\text { Supply Chain } \\
\text { Management }\end{array}$ & Emerald & 14 & 2 \\
\hline & Logistics & Emerald & 9 & 1 \\
\hline & $\begin{array}{l}\text { Marine } \\
\text { Transport }\end{array}$ & Emerald & 5 & 2 \\
\hline & Ports & Emerald & 5 & 1 \\
\hline & Shipping & Emerald & 5 & - \\
\hline & Transportation & Emerald & 5 & - \\
\hline & $\begin{array}{c}\text { Transport } \\
\text { Management }\end{array}$ & Emerald & 4 & - \\
\hline & Suppy Chain & Emerald & 3 & - \\
\hline & Transport & Emerald & 3 & - \\
\hline \multirow[t]{9}{*}{$\begin{array}{c}\text { Marine Shipping } \\
+ \text { Port } \\
\text { Integration }+ \\
\text { Supply Chain } \\
\end{array}$} & $\begin{array}{l}\text { Supply Chain } \\
\text { Management }\end{array}$ & Emerald & 14 & 2 \\
\hline & Logistics & Emerald & 9 & 1 \\
\hline & $\begin{array}{c}\text { Marine } \\
\text { Transport }\end{array}$ & Emerald & 5 & 2 \\
\hline & Ports & Emerald & 5 & 1 \\
\hline & Shipping & Emerald & 5 & - \\
\hline & Transportation & Emerald & 5 & - \\
\hline & $\begin{array}{c}\text { Transport } \\
\text { Management }\end{array}$ & Emerald & 4 & - \\
\hline & Supply Chain & Emerald & 3 & - \\
\hline & Transport & Emerald & 3 & - \\
\hline \multirow[t]{4}{*}{$\begin{array}{c}\text { Maritime } \\
\text { Transportation } \\
+ \text { Port } \\
\text { integration+ } \\
\text { Supply Chain } \\
\end{array}$} & Supply Chain & ScienceDirect & 38 & 8 \\
\hline & Ship & ScienceDirect & 29 & 2 \\
\hline & Transport & ScienceDirect & 17 & - \\
\hline & Maritime & ScienceDirect & 10 & \\
\hline
\end{tabular}


Table 1: Keyword Analysis (Continued)

\begin{tabular}{|c|c|c|c|c|}
\hline Keyword & $\begin{array}{c}\text { Keyword } \\
\text { Extension }\end{array}$ & E-Database & $\begin{array}{c}\text { Total } \\
\text { Number } \\
\text { of } \\
\text { Articles }\end{array}$ & $\begin{array}{c}\text { Relevant } \\
\text { Number } \\
\text { of } \\
\text { Articles }\end{array}$ \\
\hline $\begin{array}{c}\text { Marine Shipping } \\
\text { + Port } \\
\begin{array}{c}\text { Integration }+ \\
\text { Supply Chain }\end{array}\end{array}$ & Ship & ScienceDirect & $\mathbf{3 6}$ & $\mathbf{2}$ \\
\hline & Marine & ScienceDirect & $\mathbf{2 1}$ & - \\
\hline & Supply chain & ScienceDirect & $\mathbf{1 6}$ & - \\
\hline & Maritime & ScienceDirect & $\mathbf{1 1}$ & - \\
\hline
\end{tabular}

Table 2: Further Keyword Analysis Results

\begin{tabular}{|c|c|c|}
\hline Author(s) & Title & Journal \\
\hline $\begin{array}{l}\text { Bichou and Gray } \\
\text { (2004) }\end{array}$ & $\begin{array}{l}\text { A logistics and supply chain } \\
\text { management approach to port } \\
\text { performance measurement }\end{array}$ & $\begin{array}{l}\text { Maritime Policy \& } \\
\text { Management }\end{array}$ \\
\hline Bichou (2004) & $\begin{array}{l}\text { The ISPS code and the cost of } \\
\text { port compliance: an initial } \\
\text { logistics and supply chain } \\
\text { framework for port security } \\
\text { assessment and management }\end{array}$ & $\begin{array}{c}\text { Maritime Economics \& } \\
\text { Logistics }\end{array}$ \\
\hline $\begin{array}{l}\text { Carbone and De } \\
\text { Martino (2003) }\end{array}$ & $\begin{array}{l}\text { The changing role of ports in } \\
\text { supply-chain management: an } \\
\text { empirical analysis }\end{array}$ & $\begin{array}{l}\text { Maritime Policy \& } \\
\text { Management }\end{array}$ \\
\hline Frémont (2008) & $\begin{array}{l}\text { Empirical evidence for } \\
\text { integration and disintegration } \\
\text { of maritime shipping, port and } \\
\text { logistics activities }\end{array}$ & $\begin{array}{c}\text { OECD/ITF Joint } \\
\text { Transport Research } \\
\text { Centre Discussion Paper }\end{array}$ \\
\hline $\begin{array}{l}\text { Notteboom and } \\
\text { Rodrigue (2008) }\end{array}$ & $\begin{array}{l}\text { Containerisation, box logistics } \\
\text { and global supply chains: The } \\
\text { integration of ports and liner } \\
\text { shipping networks }\end{array}$ & $\begin{array}{c}\text { Maritime Economics \& } \\
\text { Logistics }\end{array}$ \\
\hline Panayides (2006) & $\begin{array}{l}\text { Maritime logistics and global } \\
\text { supply chains: towards a } \\
\text { research agenda }\end{array}$ & $\begin{array}{c}\text { Maritime Economics \& } \\
\text { Logistics }\end{array}$ \\
\hline $\begin{array}{l}\text { Panayides and } \\
\text { Song (2009) }\end{array}$ & $\begin{array}{l}\text { Port integration in global } \\
\text { supply chains: measures and } \\
\text { implications for maritime } \\
\text { logistics }\end{array}$ & $\begin{array}{l}\text { International Journal of } \\
\text { Logistics: Research and } \\
\text { Applications }\end{array}$ \\
\hline $\begin{array}{l}\text { Song and Lee } \\
\quad(2009)\end{array}$ & $\begin{array}{l}\text { Maritime logistics in the global } \\
\text { supply chain }\end{array}$ & $\begin{array}{c}\text { International Journal of } \\
\text { Logistics Research and } \\
\text { Applications }\end{array}$ \\
\hline
\end{tabular}


Table 2: Further Keyword Analysis Results (Continued)

\begin{tabular}{|c|l|c|}
\hline Author(s) & Title & Journal \\
$\begin{array}{c}\text { Song and } \\
\text { Panayides (2008) }\end{array}$ & $\begin{array}{l}\text { Global supply chain and } \\
\text { port/terminal: integration and } \\
\text { competitiveness }\end{array}$ & $\begin{array}{c}\text { Maritime Policy \& } \\
\text { Management }\end{array}$ \\
\hline $\begin{array}{c}\text { Yan and Qiang } \\
\text { (2008) }\end{array}$ & $\begin{array}{l}\text { Logistics and Supply Chain } \\
\text { Integration Model of Port in } \\
\text { Transportation Networks }\end{array}$ & $\begin{array}{c}\text { ICII'08 International } \\
\text { Conference } \\
\text { on Information } \\
\text { Manement, Innovation } \\
\text { Industrial Engineering }\end{array}$ \\
\hline
\end{tabular}

\section{KEY FINDINGS AND SUGGESTIONS FOR FUTURE RESEARCH}

As this study aims to specify and interpret the available literature about integration of maritime transportation to supply chains with a focus on port integration, and provide some suggestions for future research, it is essential to have information regarding related concepts such as maritime transportation and supply chains. Therefore, this part is organized as follows. The first sub-section will give information regarding the relationship between maritime transportation and supply chains, and second sub-section will conceptualize port integration to supply chains by analyzing existing literature on the changing roles of ports, and proposing some suggestions for future research.

\subsection{Maritime Transportation: The Relationship with Supply Chains}

The dramatic increase in the world population forces companies to reach for resources in a less expensive and rapid manner, which, in turn, increases the importance of maritime transportation, especially, for the supply of global resources (Goss, 1982). In that sense, maritime transportation is related with the transportation of goods (or passengers) between two seaports through sea (Tuna and Arabelen, 2013).

The demand for these, on the other hand, is derived from the world trade (Cerit, 2013). However, with the globalisation in production, consumption, and severe conditions of global competition altered the characteristics of this demand, and made it an integrated demand (Panayides, 2006). This integrated demand comes from the needs, such as, of minimizing costs or improving value, and in fact, it embraces the possession of goods and services which have been transported and 
transformed from the point of production to the point of consumption for creating added value (Panayides, 2006). Accordingly, this change in the formation of derived demand supports the supply chain perspective, because if and only if each partner creates value, the competitive advantage of the chain could be sustained (Cerit, 2013).

Beyond these, changing customer needs, in fact, have altered the global marketplace. Customers begin to require several shifts such as from products to solutions, and suppliers to networks partners (Neely et al. 2011). Solutions could be described as "individualized offers for complex customer problems that are interactively designed and whose components offer an integrative added value... so that the value is more than the sum of its components" (Sawhney, 2006; cited in Evanschitzky et al. 2011). Accordingly, the traditional customer of maritime transportation has begun to demand the application of logistics concepts, and a complete door-to-door service with the least cost and highest efficiency from a sole provider (Panayides, 2006).

Moreover, the leading mode for international freight movements is maritime transport (including ports-nodes- and shipping services links-). From a global perspective, $90 \%$ of the world trade, and $86,4 \%$ of Turkey's foreign trade is done through sea (GISBIR, 2014). This high dependence in maritime transportation has several reasons. First of all, maritime transportation is 14 times, 7 times, and 3,5 times cheaper than air, road, and railway, respectively (Koçak, 2012). Besides being cheap, it also provides a safer and eco-friendly transportation (through having minimal environmental impact), and allows carrying excessive quantity of freight at one time (especially, with the development of containerisation) (Ateş et al. 2010). These advantages make maritime transportation the dominant mode for international trade and also for supply chains (Mangan et al. 2008). Accordingly, integration, which may be physical (integration of modes of transport), economic/strategic (vertical integration, governance structure) or organizational (relational, people or process integration via organizations), emerges at the centre of maritime transportation (Panayides, 2006).

\subsection{The Changing Role of Ports and Integration of Ports to Supply Chains}

Ports have been acted both as the link between maritime and inland transport, and the interface between sea and rivers, roads, and railways, thus they have been natural sites for shipment of products from 
one transportation mode to another (Carbone and De Martino, 2003). Accordingly, traditional thinking focuses on attributes of ports such as geographic location and service efficiencies, and considers them as weak links (Yan and Qiang, 2008). However, since 1980, the market environment of ports has been continuously changing (Notteboom and Winkelmans, 2001), and so has the traditional role of ports (Yan and Qiang, 2008).

The current literature widely accepts that ports are an integral part of supply chain and their positive effects on overall performance of logistics and supply chains (Denktaş Şakar and Deveci, 2012). This leads to the idea that they should promote their respective supply chain's performance and efficiency, as well as improving their own internal efficiencies and performance (Tongzon et al. 2009). This demonstrates the competitive position of a port has also affected by its links to a supply chain, and it could not be inferred only from its internal strengths (Yan and Qiang, 2008). The authors, further, indicate that the contemporary role of ports enhanced to become locations for value-added logistics, and locations where several trade partners could meet and interact (Yan and Qiang, 2008). Similarly, Tongzon et al. (2009) state that ports are a part of a bunch of organizations which includes diverse logistics and transport operators in order to create value for the ultimate consumer. Accordingly, the altered role of ports has been conceptualized by Bichou and Gray (2005) within three perspectives. Firstly, from a logistics channel perspective, ports serve as a node and operate as a logistics centre. From a trade channel perspective, ports are key locations that the control and ownership of the channel could be classified and/or traded. Lastly, from a supply channel perspective, ports are links between outside flows and processes, and they also create patterns and processes on their own. This demonstrates, contemporary role of ports has enhanced to become networking sites, which gathers members of the chain (Panayides, 2006; Yan and Qiang, 2008). Therefore, as the role of ports has changed (See Carbone and De Martino, 2003; Bichou and Gray, 2004; 2005; Notteboom and Rodrigue, 2005), a need occurs for higher degree of coordination and cooperation in order to be successful (Song and Panayides, 2008). Thus, supply chain integration/orientation has become an interest in order to meet the needs and demands of customers, and to achieve port competitiveness (Tongzon et al. 2009).

Although current literature acknowledges the importance of port integration to ports or supply chain orientation for ports, the number of empirical studies on these issues are limited (Song and Panayides, 2008; Tongzon et al. 2009; Panayides and Song, 2009). Within these studies, 
some of them (i.e: Heaver et al., 2000; Notteboom and Winkelmans, 2001) investigate the causes and implications of port, maritime transport and logistics integration. For instance, some studies highlight the changing role of ports in the new logistics environment (Heaver et al. 2000), or in a value- driven chain system (Robinson, 2002), whereas some researchers investigate the current level of integration of ports in Turkey (i.e: Kurtuluş et al. 2015) or in Korea (Tongzon et al. 2009).

Apart from conceptualization, previous literature provides examples in terms of security and port performance measurement. As ports become more integrated to supply chains, this may produce some consequences in terms of security issues (Tongzon et al., 2009). This systems becomes vulnerable to a broad variety of crimes against both people and property, and from a broader perspective, it may be damaged or disrupted by natural hazards such as earthquakes and hurricanes (Helmick, 2008). Therefore, beyond structural requirements (i.e: International Ship and Port Security Code), these vulnerabilities could in turn cause management challenges, which require the improvement of crisis management capabilities (Barnes and Oloruntoba, 2005).

Although traditionally port performance is measured by efficiency and competitiveness, as the roles of ports have changed, researchers suggest a supply chain management approach for measuring port performance (Panayides, 2006). For instance, Bichou and Gray (2005) propose that the performance of ports could be measured according to its contribution to overall added value of the channel. While some studies (i.e: Marlow and Paixao, 2003; Paixao and Marlow, 2003) offer logistics concepts such as leanness and agility for investigating port performance, other follow an empirical approach and suggest several constructs such as value-added services (i.e: Tongzon et al. 2009) and information and communication systems (i.e: Panayides and Song, 2009). For instance, Carbone and De Martino (2003) investigate the contribution of a port to value creation through a case analysis, whereas Song and Panayides (2008) use 'use of information and communication technology', 'relationship with shipping line', 'value added service', 'integration of transport modes', and 'relationship with inland transport operators' as measures of port supply chain integration through a questionnaire survey.

\subsection{Suggestions for Further Research}

As mentioned above, conceptualization, and security and performance issues, as well as the practical aspects (i.e: integration of 
transportation modes) have been under investigation by the current literature. However, supply chain concept is complex (due to, for instance, including several parties), and it cannot be studied from one perspective (Tongzon et al. 2009), thus there is still a need to investigate organizational aspects (i.e: relational mechanisms) of integration (Panayides, 2006). Previous literature neglects this issue except a few examples. For instance, Panayides and So (2005) focus on the relationship between service provider and client in third-party logistics concept. While Tongzon et al. (2009) examine if there is a convergence of perceptions between two parties, namely terminal operators and users, through a case study, Yan and Qiang (2008) try to fulfil the gap in the literature by investigating the relationships between shipping lines and ports by providing models for port, logistics and supply chain integration. However, as mentioned above, the number of studies investigating the relationship aspect is limited, as a result; this study offers the investigation of dyadic (i.e: shipping lines and ports), triadic (i.e: shipping lines, ports and final customer), or even tetradic (i.e including the governmental side of these relationships) relationships for further research.

Moreover, since ports are considered as links to global supply chains, port competition has transformed from competition between ports to competition between chains (Yan and Qiang, 2008). Therefore, it is appropriate to benefit from the theories used in supply chain management (i.e: Agency Theory, Resource-Based View). With the reference to the suggestion of this study, researcher could benefit from Agency Theory, which is widely used in Supply Chain Management. Agency Theory focuses on exchanges between two parties (principal and agent) (Eisenhardt, 1989). In this relationship, principal grants the authority or assign the work to the agent, and as a result the welfare of principal depends on agent's judgements (Jensen and Meckling, 1976).

Apart from the relationship approach, the theory could be useful in order to understand why ports integration to supply chains fails. According to Tongzon et al. (2009), one of the reasons of the unsuccessful attempts is a party's natural tendency to get more benefits resulting from the integration, and this creates conflict of interests. Agency Theory also states that one of the parties, namely agent, can shirk or behave opportunistically due to different goals or risk preferences (Bergen et al. 1992), and provides some getaways in order to avoid this. Thus, the literature on maritime transportation could obtain a new perspective by using Agency Theory as a theoretical foundation. 
Another theory, which could be beneficial for researcher is, Resource-Based View (RBV). In general, RBV sees a firm as a bundle of resources and capabilities, thus investigates the relationship between firm's resources and capabilities and its performance (Barney, 1991). In that way, it is possible to understand how companies create competitive advantage (Halawi et al. 2005) and how differences occur in the long term performances between companies (Cousins et al. 2008: 34). Therefore, developing and maintaining strategic relationships could be seen as an organizational capability, which, according to RBV, creates sustainable competitive advantage (Tongzon et al. 2009). Accordingly, from a practical point, this theory could be used as a reference point for benchmarking a successful integration.

Another future research perspective could be a different approach, dynamic capabilities approach, which is developed from RBV. Ports, as a part of maritime transportation, operate in a continuously changing environment. Moreover, as mentioned above, the integration may create management challenges, which require the improvement of some capabilities, such as crisis management capabilities (Barnes and Oloruntoba, 2005). Dynamic capabilities approach aims to explain the reason of how some companies gaining competitive advantage in continuously changing environments (Eisenhardt and Martin, 2000), and in that sense, dynamic capabilities are described as "the capacity of an organization to purposefully create, extend or modify its knowledgerelated resources, capabilities or routines to pursue improved effectiveness" (Salunke et al. 2011). This means long-term competitive advantage could be achieved through resource configurations which managers would develop employing dynamic capabilities (Eisenhardt and Martin, 2000).

Dynamic capabilities approach mostly studied in service and management innovation literature, however, globalized markets created market environments, where there is dispersion of both geographical and organizational sources, and where dynamic capabilities are appropriate for gaining competitive advantage (Beske, 2012). When the integration of maritime transportation, especially port integration, to supply chains is the subject, it is obvious that the aim is to provide services, and integration has a managerial side as well as structural requirements (i.e: International Ship and Port Security Code). Therefore, taking a dynamic capabilities approach may help managers to stay competitive in a continuously changing environment. 


\section{CONCLUSION}

In order to survive within severe market conditions, organizations realized the importance of designing and coordinating their supply and distribution networks (Sengupta et al. 2006). Accordingly, the objective of SCM is considered to be the integration and coordination of all organizations and activities, and only the development of an integrated supply chain would create competitive advantage for companies through helping them to react to the conditions of dynamic markets (Stevens, 1989).

Another dramatic change, the rapid increase in world population, forces companies to reach for resources in a less expensive and rapid manner, which, in turn, increases the importance of maritime transportation, especially, for the supply of global resources (Goss, 1982). With the effects of globalizations, the characteristics of demand for maritime transportation, and also the customer needs have changed. Accordingly, the traditional role of ports in maritime transportation has altered which, in turn, create a need for a higher degree of coordination and cooperation in order to be successful (Song and Panayides, 2008). Thus, supply chain integration/orientation of maritime transportation, as well as ports, has become an interest in order to meet the needs and demands of customers, and to achieve port competitiveness (Tongzon et al. 2009).

The research, on the other hand, on the integration of maritime transportation, especially port integration, to supply chains is in its infancy phase. Although there are studies regarding conceptualization, security, and performance issues, as well as the practical aspects (i.e: integration of transportation modes), the research on relational aspect needs to be investigated deeper in the future.

Since there are many parties involved in the process, further research could focus on dyadic, triadic or even tetradic relationships, and may benefit from theories frequently used in Supply Chain Management literature, such as Agency Theory and RBV. Agency Theory mainly focuses on exchanges between two parties (principal and agent) (Eisenhardt, 1989), however the theory is expanded by investigating relationships which involve multi-principal or multi-agent. Moreover, the literature on maritime transportation could obtain a new perspective by using RBV and/or Dynamic Capabilities Approach as theoretical foundations. While RBV investigates the relationship between firm's resources and capabilities, and its performance, Dynamic Capabilities 
Approach explains why some companies gain competitive advantage in continuously changing environments. Since ports, as a part of maritime transportation, operate in a continuously changing environment, these theories, mostly used in SCM literature, would provide a new perspective, and aid to maintain competitiveness.

\section{REFERENCES}

Alvarado, U. and Kotzab, H. (2001). Supply chain management: The integration of logistics in marketing. Industrial Marketing Management, 30(2), 183-198.

Ateş, A., Karadeniz, Ş. and Esmer, S. (2010). Dünya konteyner taşımacılığında Türkiye'nin yeri. Dokuz Eylül Üniversitesi Denizcilik Fakültesi Dergisi, 2(2), 83-98.

Barnes, P. and Oloruntoba, R. (2005). Assurance of security in maritime supply chains: conceptual issues of vulnerability and crisis management. Journal of International Management, 11 (4), 519-540.

Barney, J. (1991). Firm resources and sustained competitive advantage. Journal of Management, 17(1), 99-120.

Bergen, M., Dutta, S. and Walker, O. J. (1992). Agency relationships in marketing: A review of the implications and applications of agency and related theories. The Journal of Marketing, 56 (3), 1-24.

Beske, P. (2012). Dynamic capabilities and sustainable supply chain management. International Journal of Physical Distribution \& Logistics Management, 42(4), 372-387.

Bichou, K. (2004). The ISPS code and the cost of port compliance: an initial logistics and supply chain framework for port security assessment and management. Maritime Economics \& Logistics, 6(4), 322-348.

Bichou, K. and Gray, R. (2004). A logistics and supply chain management approach to port performance measurement. Maritime Policy \& Management, 31(1), 47-67.

Bichou, K. and Gray, R. (2005). A critical review of conventional terminology for classifying seaports. Transportation Research Part A: Policy and Practice, 39(1), 75-92. 
Burgess, K., Singh, P. and Koroglu, R. (2006). Supply chain management: A structured review and implications for future research. International Journal of Operations \& Production Management, 26(7), 703-729.

Carbone, V. and Martino, M. D. (2003). The changing role of ports in supply-chain management: an empirical analysis. Maritime Policy \& Management, 30(4), 305-320.

Cerit, A.G. (2013) Denizcilik İşletmeleri Yönetimi. A. G. Cerit, D.A. Deveci and S. Esmer (Ed.), Denizcilik Işletmeleri Yönetimi (s.3-21). İstanbul: Beta Yayınları.

Christopher, M. (2010). Logistics and Supply Chain Management. 4th ed. Edinburgh: Prentice Hall.

Cousins, P., Lamming, R., Lawson, B. and Squire, B., (2008). Strategic Supply Management: Principles, Theories and Practice. London: FT/Prentice-Hall.

Croom, S., Romano, P. and Giannakis, M. (2000). Supply chain management: An analytical framework for critical literature review. European Journal of Purchasing \& Supply Management, 6, 67-83.

Denktaş Şakar, G. and Deveci, D.A. (2012). Intermodal transportorientation of ports: A focus group study. In: Proceedings of World conference on Transport Research Society, Sig 2 Key Developments in Port and Maritime Sector. Antwerp, Belgium.

Eisenhardt, K. M. (1989). Agency theory: An assessment and review. Academy of Management Review, 14 (1), 57-74.

Eisenhardt, K. M. and Martin, J. A. (2000). Dynamic capabilities: What are they? Strategic Management Journal, 21(10/11), 1105-1121.

Evanschitzky, H., Wangenheim, F. and Woisetschläger, D. (2011). Service \& solution innovation: Overview and research agenda. Industrial Marketing Management, 40 (5), 657-660.

Frémont, A. (2008). Empirical evidence for integration and disintegration of maritime shipping, port and logistics activities (No. 2009-1). OECD/ITF Joint Transport Research Centre Discussion Paper. 
Goss, R.O. (1982). Politics and paradigms, or: self interest and the sea. Maritime Policy and Management. 9(3), 165-173.

Halawi, L. A., Aronson, J.E. and McCarthy, R.V. (2005). Resource-based view of knowledge management for competitive advantage. The Electronic Journal of Knowledge Management, 3 (2), 75-86.

Heaver, T, Meersman, H, Moglia, F. and Van de Voorde, E. (2000). Do mergers and alliances influence European shipping and port competition? Maritime Policy and Management, 27 (4), 363-373.

Helmick, J. S. (2008). Port and maritime security: A research perspective. Journal of Transportation Security, 1(1), 15-28.

Jensen, M. C. and Meckling, W. H., (1976). Theory of the firm: managerial behavior, agency costs, and ownership structure. Journal of Financial Economics, 3(4), 305-360.

Kurtuluş, E., Karataş Çetin, Ç. and Deveci, D.A. (2015). Evaluating container terminal supply chain integration from users perspective. In: Proceedings of European Conference on Shipping Intermodalism and Ports, Chios, Greece.

Lee, H. and Fernando, Y. (2015). The antecedents and outcomes of the medical tourism supply chain. Tourism Management, 46, 148-157.

Lummus, R., Krumwiede, D. and Vokurka, R. (2001). The relationship of logistics to supply chain management: Developing a common industry definition. Industrial Management \& Data Systems, 101(8), 426-431.

Mangan, J., Lalwani, C. and Butcher, T. (2008). Global Logistics and Supply Chain Management. John Wiley \& Sons.

Marlow, P. B. and Paixao, A. C. (2003). Measuring lean ports performance. International Journal of Transport Management, 1(4), 189202.

Mentzer, J. T., DeWitt, W., Keebler, J. S., Min, S., Nix, N. W., Smith, C. D. and Zacharia, Z. G. (2001). Defining supply chain management. Journal of Business Logistics, 22(2), 1-25. 
Neely, A., Benedittini, O. and Visnjic, I. (2011). The servitization of manufacturing: Further evidence. In: Proceedings of 18th European Operations Management Association Conference. Cambridge.

Notteboom, T.E. and Rodrigue, J.P. (2005). Port regionalization: towards a new phase in port development. Maritime Policy \& Management, 32 (3), 297-313.

Notteboom, T. and Rodrigue, J. P. (2008). Containerisation, box logistics and global supply chains: The integration of ports and liner shipping networks. Maritime Economics \& Logistics, 10 (1), 152-174.

Notteboom, T. and Winkelmans, W. (2001). Structural changes in logistics: how will port authorities face the challenge?, Maritime Policy \& Management, 28(1), 71-89.

Paixao, AC. and Marlow, P. B. (2003). Fourth generation ports - a question of agility? International Journal of Physical Distribution and Materials Management, 33(4), 355-376.

Panayides, P. M. (2006). Maritime logistics and global supply chains: towards a research agenda. Maritime Economics \& Logistics, 8 (1), 3-18.

Panayides, P. M. and So, M. (2005). The impact of integrated logistics relationships on third-party logistics service quality and performance. Maritime Economics \& Logistics, 7(1), 36-55.

Panayides, P. M. and Song, D. W. (2009). Port integration in global supply chains: measures and implications for maritime logistics. International Journal of Logistics: Research and Applications, 12(2), 133-145.

Robinson, R. (2002). Ports as elements in value-driven chain systems: The new paradigm. Maritime Policy and Management, 29 (3), 241-255.

Salunke, S., Weerawardena, J. and McColl-Kennedy, J. R. (2011). Towards a model of dynamic capabilities in innovation-based competitive strategy: insights from project-oriented service firms. Industrial Marketing Management, 40(8), 1251-1263.

Sengupta, K., Heiser, D. and Cook, L. (2006). Manufacturing and service supply chain performance: A comparative analysis. The Journal of Supply Chain Management, 42 (4), 4-15. 
Song, D. W. and Lee, P. T. (2009). Maritime logistics in the global supply chain. International Journal of Logistics Research and Applications, 12(2), 83-84.

Song, D. W. and Panayides, P. M. (2008). Global supply chain and port/terminal: integration and competitiveness. Maritime Policy \& Management, 35 (1), 73-87.

Stevens, G. (1989). Integrating the supply chain. International Journal of Physical Distribution and Materials Management, 8(8), 3-8.

Tuna, O. and Arabelen, G. (2013). Deniz Ulaştırma Lojistiği. A.G.; Deveci, A.; Esmer,S. (Eds), Denizcilik Işsletmeleri Yönetimi, (s:533-561), İstanbul: Beta Basım.

Tongzon, J., Chang, Y. T. and Lee, S. Y. (2009). How supply chain oriented is the port sector?. International Journal of Production Economics, 122(1), 21-34.

Woo, S. H., Pettit, S. J. and Beresford, A. K. (2013). An assessment of the integration of seaports into supply chains using a structural equation model. Supply Chain Management: An International Journal, 18 (3), 235-252.

Xinyue, H. and Yongli, T. (2008). Integrated Tourism Service Supply Chain Management: Concept and Operations Processes. Nanjing, IEEE .

Yan, Y. and Qiang, Z. (2008). Logisitcs and Supply Chain Integration Model of Port in Transportation Networks. In: Proceedings of International Conference on Information Management, Innovation Management and Industrial Engineering, ICIII'08. (Vol. 2, 402-406). IEEE.

\section{Internet References:}

GISBIR (2014). Gemi İnşa, Bakım-Onarım Sektör Raporu.

http://www.gisbir.com/content/uploads/kurumsal/dosya/GISBIRSektorRa poru2014.pdf , Access Date: 02.01.2016

Koçak, İ.H. (2012). Dünya'da ve Türkiye'de Ekonomik Gelişmeler ve Deniz Ticaretine Yansimaları.

http://www.kugm.gov.tr/BLSM_WIYS/DTGM/tr/Kitaplar/20121031_10 3920_64032_1_64351.pdf. , Access Date: 02.01.2016 
